\title{
3'-coterminal subgenomic RNAs and putative cis-acting elements of Grapevine leafroll-associated virus 3 reveals 'unique' features of gene expression strategy in the genus Ampelovirus
}

Sridhar Jarugula', Siddarame Gowda², William O Dawson², Rayapati A Naidu*

\begin{abstract}
Background: The family Closteroviridae comprises genera with monopartite genomes, Closterovirus and Ampelovirus, and with bipartite and tripartite genomes, Crinivirus. By contrast to closteroviruses in the genera Closterovirus and Crinivirus, much less is known about the molecular biology of viruses in the genus Ampelovirus, although they cause serious diseases in agriculturally important perennial crops like grapevines, pineapple, cherries and plums.

Results: The gene expression and cis-acting elements of Grapevine leafroll-associated virus 3 (GLRaV-3; genus Ampelovirus) was examined and compared to that of other members of the family Closteroviridae. Six putative 3'-coterminal subgenomic (sg) RNAs were abundantly present in grapevine (Vitis vinifera) infected with GLRaV-3. The sgRNAs for coat protein (CP), p21, p20A and p20B were confirmed using gene-specific riboprobes in Northern blot analysis. The 5'-termini of sgRNAs specific to CP, p21, p20A and p20B were mapped in the 18,498 nucleotide (nt) virus genome and their leader sequences determined to be $48,23,95$ and $125 \mathrm{nt}$, respectively. No conserved motifs were found around the transcription start site or in the leader sequence of these sgRNAs. The predicted secondary structure analysis of sequences around the start site failed to reveal any conserved motifs among the four sgRNAs. The GLRaV-3 isolate from Washington had a 737 nt long $5^{\prime}$ nontranslated region (NTR) with a tandem repeat of $65 \mathrm{nt}$ sequence and differed in sequence and predicted secondary structure with a South Africa isolate. Comparison of the dissimilar sequences of the $5^{\prime}$ NTRs did not reveal any common predicted structures. The $3^{\prime}$ NTR was shorter and more conserved. The lack of similarity among the cis-acting elements of the diverse viruses in the family Closteroviridae is another measure of the complexity of their evolution.

Conclusions: The results indicate that transcription regulation of GLRaV-3 sgRNAs appears to be different from members of the genus Closterovirus. An analysis of the genome sequence confirmed that GLRaV-3 has an unusually long 5'NTR of 737 nt compared to other monopartite members of the family Closteroviridae, with distinct differences in the sequence and predicted secondary structure when compared to the corresponding region of the GLRaV-3 isolate from South Africa.
\end{abstract}

\section{Background}

The family Closteroviridae comprises genera with monopartite genomes, Closterovirus and Ampelovirus, and with bipartite and tripartite genomes, Crinivirus [1]. They are semi-persistently transmitted by aphids

\footnotetext{
* Correspondence: naidu@wsu.edu

'Department of Plant Pathology, Irrigated Agriculture Research and Extension Center, Washington State University, Prosser, WA 99350, USA Full list of author information is available at the end of the article
}

(closteroviruses), whiteflies (criniviruses) or mealybugs/ scale insects (ampeloviruses) and represent the most complex plant viruses infecting a broad range of agriculturally important crops [2]. Closteroviruses in the genera Closterovirus and Crinivirus have complex genome organizations and expression strategies unique to the viruses in the family Closteroviridae [[3-12] and citations in these references]. The unusually long, highly flexuous filamentous particles have bipolar architecture

\section{() Biomed Central}


composed of at least two capsid proteins which encapsidate single-stranded, positive-sense RNA genomes of $\sim 15-20 \mathrm{~kb}[7,8]$. The replication-associated proteins are encoded by a signature 'replication gene block', made up of domains for one or two papain-like proteinases, methyl transferase- and helicase-like domains with large interdomain region, and $\mathrm{a}+1$ frameshift to express an RNA-dependent RNA polymerase-like domain. The other genes are encoded in 7-12 open reading frames (ORFs) and are expressed through a nested set of $3^{\prime}$ coterminal subgenomic (sg) mRNAs. Among these genes is a signature 'quintuple gene module' involved largely in assembly of virions. The other ORFs vary in number and arrangement and appear to be unique to each species in the family.

Based on the well-studied closteroviruses and criniviruses, the different 3 ' genes are expressed at greatly variable amounts, suggesting precise regulation of different proteins in relation to the amounts needed during the virus life cycle. With Citrus tristeza virus (CTV) as a model, there appear to be general rules that determine the levels of production of the different $3^{\prime}$-coterminal sgRNAs. First, genes located nearer to the $3^{\prime}$ terminus tend to be expressed at higher levels than internal genes. The second rule is that ORFs with an upstream nontranslated region are generally expressed higher than those ORFs that overlap or do not have an upstream nontranslated region. With CTV, the cisacting elements that regulate the level of expression of genes in the $3^{\prime}$ half of the genome are located immediately upstream to the transcription start site of their sgRNAs. These elements generally consist of one or two stem-loop (SL) structures with a downstream (plus sense) +1 site corresponding to the $5^{\prime}$ terminal adenosine of the sgRNA $[13,14]$. Additionally, an adenylate appears to be the $5^{\prime}$-terminus of all sgRNAs encoded by CTV similar to the $5^{\prime}$ terminus of the genomic RNA [15]. In the case of Beet yellows virus (BYV), several sgRNAs have adenylate at their $5^{\prime}$ termini, with the exception of BYV p6 sgRNA that contains a guanylate similar to the $5^{\prime}$ terminus of the genomic RNA $[16,17]$. On the other hand, the 5 terminal nucleotide of the sgRNAs of the crinivirus Sweet potato chlorotic stunt virus was reported to be variable, having adenylate, guanylate or uridylate, and the $5^{\prime}$ ends of genomic RNA 1 and RNA 2 have conserved guanylates [18].

By contrast, much less is known about the molecular biology of closteroviruses in the genus Ampelovirus, although they cause serious diseases in agriculturally important perennial crops like grapevines [19], pineapple [20], cherries [21] and plums [22]. Grapevine leafroll-associated virus 3 (GLRaV-3), the type member of the genus Ampelovirus, represents the second largest virus in the family Closteroviridae with a monopartite genome of 18,498 nt [23], after CTV that has a 19,293 nt genome [24]. Similar to CTV, molecular variants of
GLRaV-3 have been documented using partial [25] and full length sequences $[23,26,27]$. An analysis of the sequences of GLRaV-3 isolates showed similar genome organization with a relatively high degree of nucleotide conservation across their genome, except in the $5^{\prime}$ nontranslated region (NTR). Also, the length of the $5^{\prime} \mathrm{NTR}$ was reported to be different for different isolates. The South Africa isolate was reported to have a $737 \mathrm{nt}$ long $5^{\prime}$ NTR [23], whereas New York [26] and Chile [27] isolates were reported to have $158 \mathrm{nt} 5^{\prime} \mathrm{NTRs}$.

The genome organization of GLRaV-3 is shown in Fig. 1. Unlike other viruses in the genera Closterovirus and Ampelovirus, GLRaV-3 contains two small ORFs ( $\mathrm{p} 7$ and p4) nearest to the 3 '-terminus of the genome. In the case of BYV and CTV, the most 3'-proximal ORFs encode highly expressed $\sim$ p21 $\mathrm{kDa}$ and $\sim \mathrm{p} 23 \mathrm{kDa}$ proteins, respectively, that function as replication enhancers $[28,29]$. In GLRaV-3, p20B, the counterpart to the BYV p21 ORF or CTV p23 ORF, is present upstream of $\mathrm{p} 7$ and $\mathrm{p} 4$. Thus, it appears that $\mathrm{p} 7$ and $\mathrm{p} 4$ are unique to GLRaV-3 and counterparts of these genes are not present in other closteroviruses. Additionally, the order of arrangement of $\mathrm{CP}$ and $\mathrm{CPm}$ is different in GLRaV-3 with the latter located towards the $3^{\prime}$-terminus of the virus genome, when compared to their arrangement in viruses of the genus Closteroviruses. Moreover, the size of CPm of GLRaV-3 is much larger than that of BYV and CTV.

In this study, we examined the gene expression strategy and cis-acting elements of GLRaV-3 in comparison to the other members of the Closteroviridae. Four of the eleven putative 3 '-coterminal sgRNAs accumulated at high levels, two at intermediate levels, and the rest at low levels in naturally infected grapevine tissues. The transcription start sites of the four abundantly expressed sgRNAs were determined relative to the genomic RNA and their leader sequences and upstream sequences, where cis-acting sequences would be expected, were analyzed as a first step to elucidate gene expression strategy in ampeloviruses. The results indicate that transcription regulation of GLRaV-3 sgRNAs appears to be different from members of the genus Closterovirus. An analysis of the genome sequence confirmed that GLRaV-3 has an unusually long $5^{\prime}$ NTR of 737 nt compared to other monopartite members of the family Closteroviridae, with distinct differences in the sequence and predicted secondary structure when compared to the corresponding region of the GLRaV-3 isolate from South Africa. In contrast, the $3^{\prime} \mathrm{NTR}$ of the two isolates is highly conserved.

\section{Results}

Some 3 '-coterminal sgRNAs are abundantly present in grapevines naturally infected with GLRaV-3

By analogy with BYV [4] and CTV [6], the two well studied members of the genus Closterovirus, ORFs 


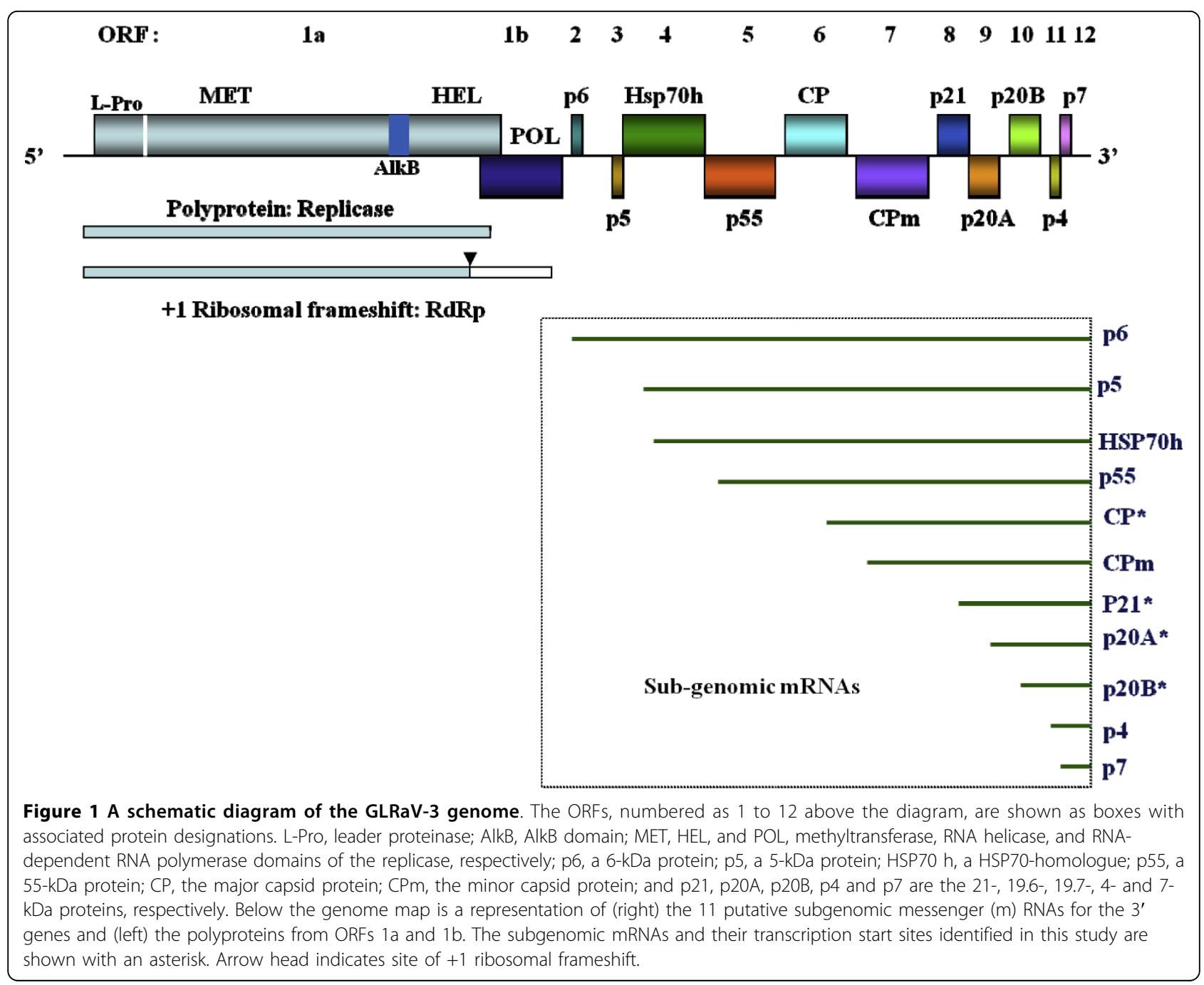

2 through 12 , covering the $3^{\prime}$ half of the GLRaV-3 genome (Fig. 1) would be expected to be expressed via eleven 3'-coterminal sgRNAs. As a first step towards comparative exploration of replication strategy of viruses in the genus Ampelovirus, we investigated the presence of sgRNAs in grapevine naturally infected with GLRaV3. Total RNA preparations from scrapings of bark tissues were analyzed by Northern blot hybridization with positive-stranded RNA-specific riboprobes corresponding to nts 17,899 to 18,498 at the $3^{\prime}$ end of GLRaV-3 genomic RNA. As shown in Fig. 2, four sgRNAs were present at higher levels and they were putatively identified as specific to p20B (ORF 10), p20A (ORF 9), p21 (ORF 8) and CP (ORF 6) genes. The two sgRNAs for $\mathrm{p} 4$ (ORF11) and p7 (ORF12) were not resolved due to the small differences in their sizes and appeared as a single moderately expressed band in Northern blots. The three barely visible bands were putatively identified as sgRNAs corresponding to CPm (ORF 7), p55 (ORF 5) and p5
+HSP70 h (ORFs 3 and 4) genes. The specificity of the abundantly-accumulated sgRNAs to CP, p21, p20A and p20B genes was further confirmed by hybridization with riboprobes prepared using gene-specific sequences (Fig. 2). The riboprobe specific to the CPm hybridized weakly with the corresponding sgRNA band. Since the riboprobe showed strong hybridization with sgRNA of the $\mathrm{CP}$, the observed weak signal further confirms that the sgRNA of CPm is poorly expressed. Among the four sgRNAs that accumulated at higher levels, the sgRNA corresponding to $\mathrm{p} 20 \mathrm{~B}$ gene accumulated at the highest level, followed by sgRNAs for p21, p20A and CP, respectively (Fig. 2). These results suggest that $3^{\prime}$ coterminal sgRNAs accumulate at variable amounts, reflecting differences in their expression levels and/or turnover rates in infected grapevine tissues. None of the sgRNAs were detected with a riboprobe specific to the $5^{\prime}$ NTR (data not shown) further confirming that they are $3^{\prime}$-coterminal to the virus genome. 


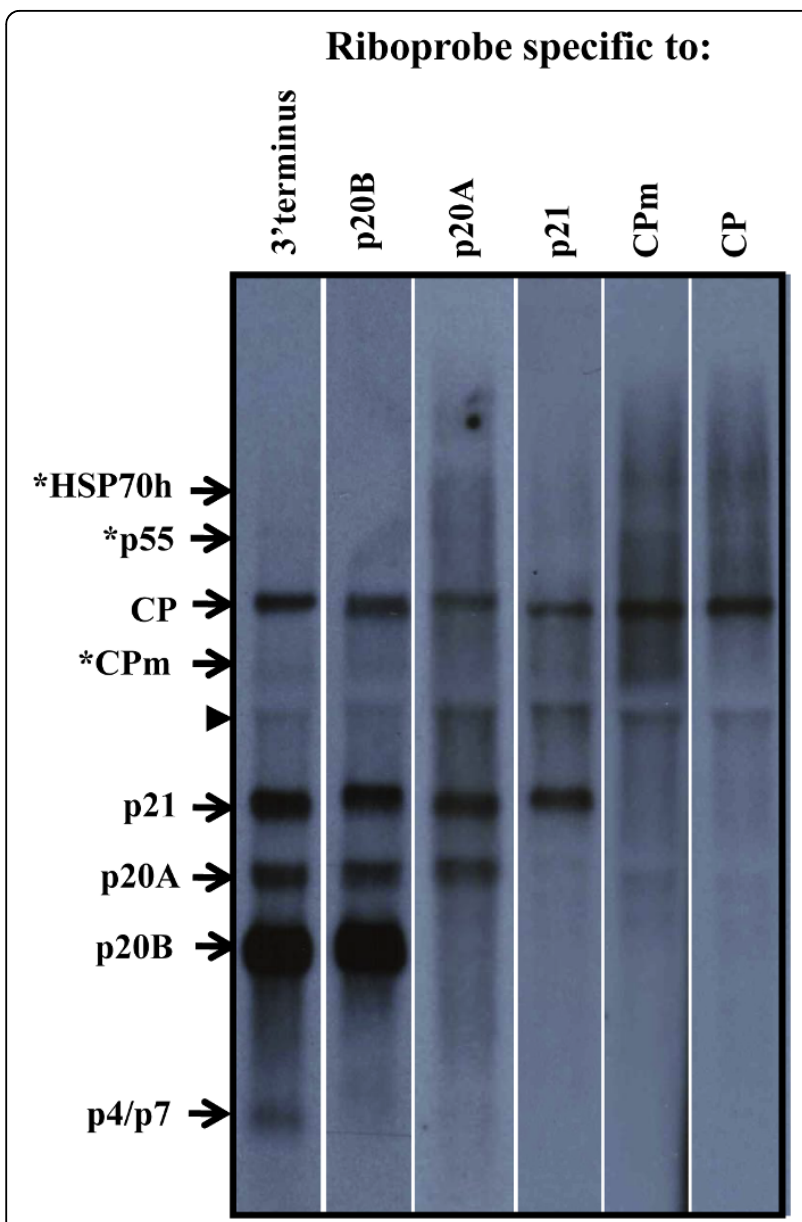

Figure 2 Northern blot analysis of total RNA extracted from grapevine (cv. Merlot) infected with GLRaV-3. Northern blot hybridizations were carried out using a positive-stranded genespecific riboprobes containing 3'terminus, p20A, p21, CPm, and CP sequences. Position of subgenomic (sg) RNAs is indicated by arrows on the left. Location of sgRNAs for CPm, p55 and HSP70h were tentative and indicated with an asterisk. The non-specific band present in all lanes is indicated by an arrow head.

\section{GLRaV-3 has an unusually long 5'NTR}

In order to characterize the sgRNAs further and map their locations in the virus genome, we needed to obtain the sequence of the Washington isolate of GLRaV-3. Although sequence is available for South Africa, Chile and New York isolates of GLRaV-3, considerable variation in their genome size between 17,919 and 18,498 nt warranted generating full genome sequence of the Washington isolate. In addition, having genome sequence information for the parental isolate of GLRaV3 would enable mapping the 5 -transcription start site of sgRNAs more precisely in the cognate viral genome sequence. Due to its large size, the entire genome of GLRaV-3 was amplified into seven segments using virus-specific primers (Additional file 1, Figure S1 and Table S1). The cDNA clones representing each of the genomic segments were sequenced by directed sequencing protocol ("DNA walking") using progressive sequence-specific primers designed based on the partial nucleotide sequence obtained. This strategy, instead of cloning and sequencing by random oligonucleotide primers, decreased the number of steps required for determining the complete genome sequence of the virus and assembling the consensus sequence into a full-length genomic RNA sequence.

The RNA genome sequence of Washington isolate of GLRaV-3 was determined to be $18,498 \mathrm{nt}$ long and it was deposited in GenBank under the accession no. GU983863. The genome contains thirteen putative ORFs with 737 nt long 5'NTR and 277 nt long 3'NTR (Fig. 1). The genome organization of Washington isolate was identical to GLRaV-3 isolates from New York [26], Chile [27] and South Africa [23]. The sizes of different ORFs and the 3 'NTR were similar between all isolates (Additional file 1, Table S2). However, the size of the $5^{\prime}$ NTR was significantly different, with New York and Chile isolates containing $158 \mathrm{nt}$, and South Africa and Washington isolates having $737 \mathrm{nt}$. In general, the genome of Washington isolate of GLRaV-3, downstream of $5^{\prime}$ NTR sequence, showed higher level of nucleotide sequence identity with corresponding sequence of virus isolates from New York ( 97\%) and Chile ( 99\%) than with South Africa isolate ( 92\%). Overall, higher sequence identity values indicate that Washington isolate is closely related to GLRaV-3 isolates from New York and Chile than to the South Africa isolate (Additional file 1, Table S2).

Due to the discrepancy in the size of $5^{\prime} \mathrm{NTR}$ of the four GLRaV-3 isolates, we examined the sequence of $5^{\prime}$ NTR of several isolates from six cultivars: four wine grape cultivars (Cabernet Sauvignon, Syrah, Merlot, Chardonnay), one table grape cultivar (Thomson Seedless) and one juice grape cultivar (Concord) planted in geographically widely separated regions in the US. The 5'RACE system was employed to verify the exact size of 5 'NTR using two gene-specific downstream primers complementary to 860 to $883 \mathrm{nt}$ (primer M1012) and 1034 to $1059 \mathrm{nt}$ (primer M1013) of ORF1a of the Washington isolate. The expected DNA fragments from RT-PCR amplification would be $\sim 304 \mathrm{nt}$ and $\sim 480 \mathrm{nt}$, if the $5^{\prime} \mathrm{NTR}$ is $158 \mathrm{nt}$ in size as reported in New York and Chile isolates or it would be $\sim 883 \mathrm{nt}$ and $1059 \mathrm{nt}$, if the $5^{\prime} \mathrm{NTR}$ is $737 \mathrm{nt}$ in size as found in isolates from Washington and South Africa (Fig. 3a). Using the abridged anchor primer supplied with the 5'RACE kit as an upstream primer (primer AAP), a single product of $\sim 883$ bp and $\sim 1059$ bp were amplified with virus-specific primers M1012 and M1013, respectively (Fig. 3b). Sequence analysis of eight independent clones for each isolate showed that the size of $5^{\prime} \mathrm{NTR}$ is $737 \mathrm{nt}$ with 


\section{$\mathbf{a}$}

\section{STTR STTR (579 nt) (158 nt) \\ Polyproteln: Replicase}

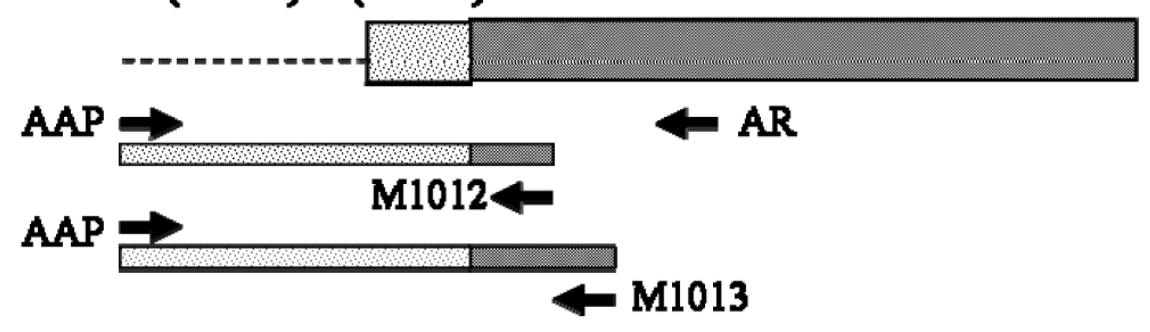

b

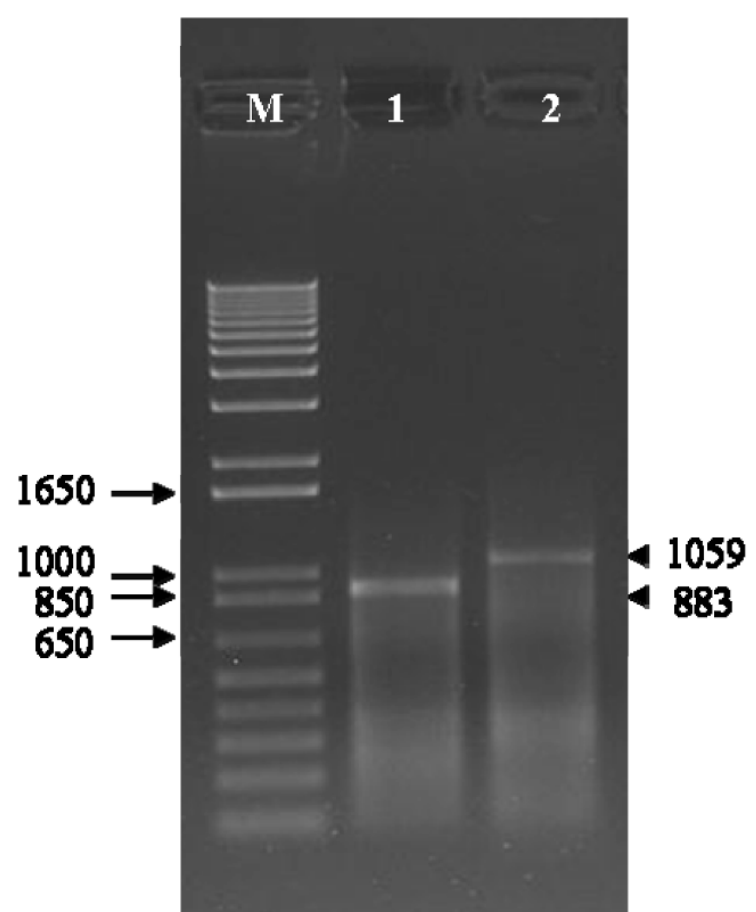

Figure 3 RACE analysis of 5'NTR of GLRaV-3. (a) The schematic diagram showing the locations of primers used and expected size of amplicons and (b) agarose gel showing virus-specific DNA fragments (shown by arrow head on the right) amplified from cDNA made using primer AR. Lane 1 shows 883 bp fragment amplified with primers AAP and M1012 and lane 2 shows 1059 bp fragment amplified with primers AAP and M1013 primers. Lane M shows $1 \mathrm{~kb}$ plus DNA marker (Invitrogen) for estimating the size of amplified DNA fragment. The size of marker DNA bands is indicated to the left. See Materials and methods for primer details.

98-100\% sequence identity with corresponding sequence of the Washington isolate. The $5^{\prime} \mathrm{NTR}$ is A-U rich (22.12\% As and $47.49 \%$ Us) and showed $83 \%$ nucleotide identity with the $5^{\prime} \mathrm{NTR}$ of the South Africa isolate. The 158 nt 5 'NTR sequence of the Washington isolate immediately upstream of ORF1a showed 100\% identity with corresponding $5^{\prime}$ NTR sequences of New York and Chile isolates. From these results it is clear that the 737 nt $5^{\prime}$ NTR is indeed authentic and an unusually long nontranslated sequence could be characteristic of GLRaV-3 including New York and Chile isolates.
The 5'NTR of GLRaV-3 isolates shows complex but distinct structural architecture than 3'NTR

Although the $5^{\prime} \mathrm{NTRs}$ of several GLRaV-3 isolates from the US and South Africa were of the same size, pairwise comparison showed non-uniform sequence identity distributed across the entire sequence (Fig. 4a). An unusually long stretch of 65 nt tandem repeat was observed between nucleotides 187 to 315 in the $5^{\prime} \mathrm{NTR}$ of all isolates of GLRaV-3 from the US sequenced in this work, where the first repeat was found between nucleotides 187-250 and the second between 251-315. Four 


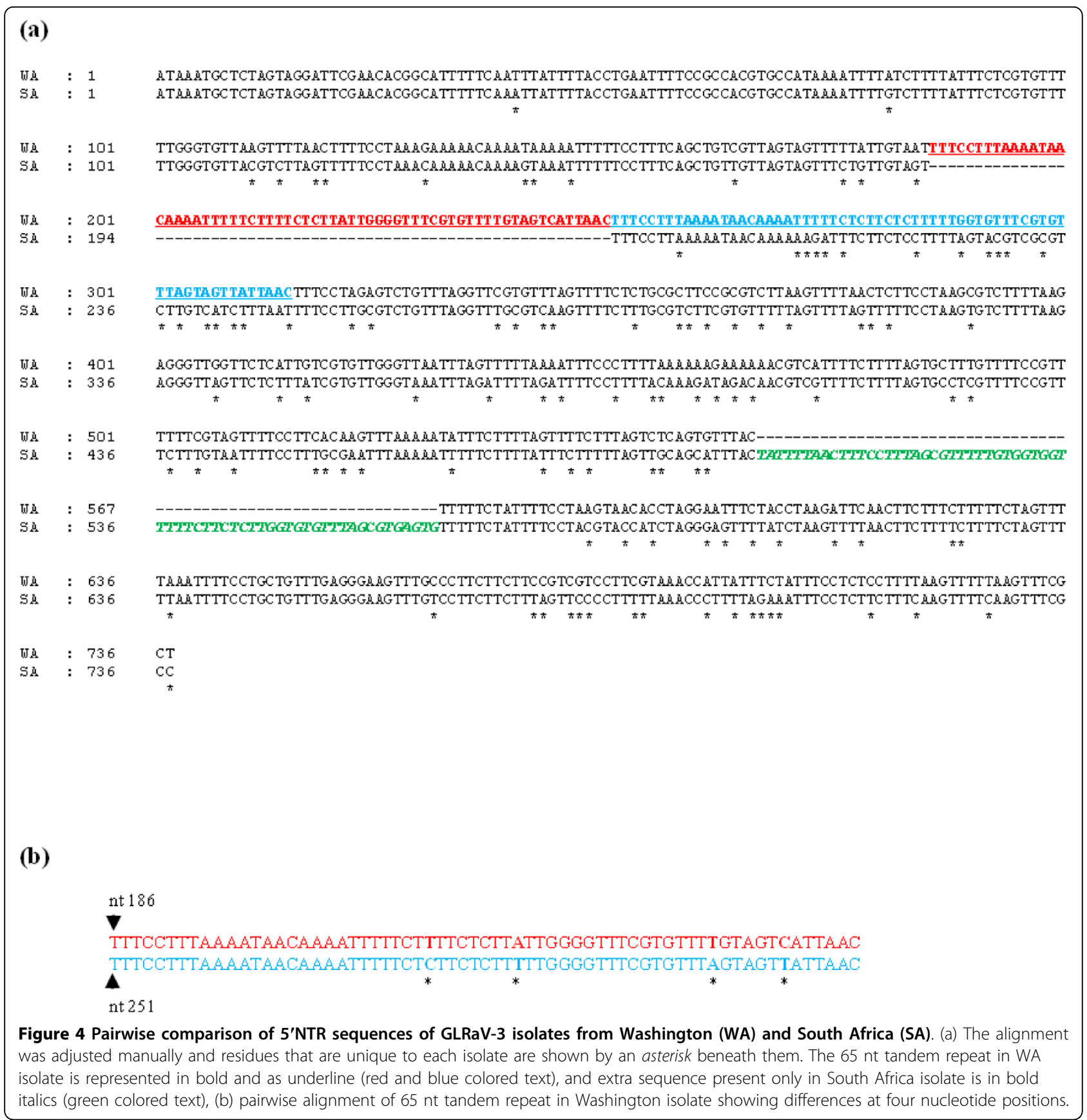

nucleotide differences were observed in the tandem repeat sequences and these differences were distributed randomly in the entire length of the repeat (Fig. 4b). Whereas, such a signature tandem repeat was absent in $5^{\prime}$ NTR of the South Africa isolate. However, the South Africa isolate has an additional 65 nt sequence that maintained $737 \mathrm{nt}$ size of its $5^{\prime}$ NTR (Fig. 4a). Alignment of $5^{\prime}$ NTR sequences showed high sequence identity in the end sequences and in the middle portion with two distinct, highly variable regions in between. To further examine differences in the $5^{\prime} \mathrm{NTR}$ of GLRaV-3 isolates, we compared their predicted secondary structure using computational calculations at the MFOLD web server [30]. The 5'NTR of Washington and South Africa isolates folded into a complex structure consisting of a long SL structure with several substructural hairpins of variable lengths (Fig. 5a). This indicated that, although both isolates of GLRaV-3 have similar size 5 'NTRs, the primary sequence and the predicted secondary structural architecture differed between them. In contrast, the 277 
with the $5^{\prime}$ most one forming a complex structure containing four substructural hairpins of variable length.

(a)

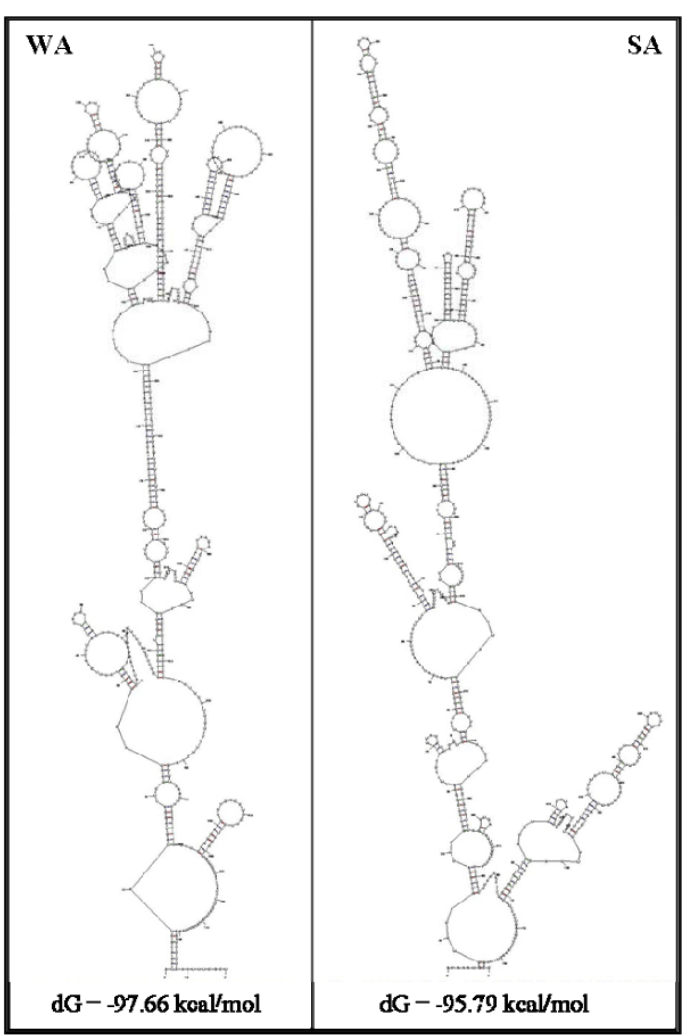

(b)

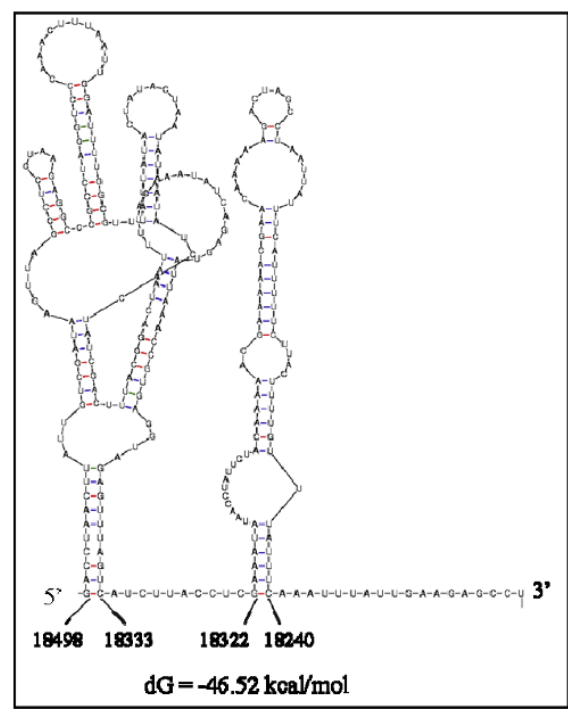

Figure 5 The computer-predicted secondary structure of the NTRs of GLRaV-3. (a) 5'NTR of Washington (WA) and South Africa $(\mathrm{SA})$ isolates and (b) $3^{\prime} \mathrm{NTR}$ of WA isolate (complement).

nt 3'NTR of Washington, New York, Chile and South Africa isolates of GLRaV-3 showed $>97 \%$ similarity and folded into identical secondary structures (complementary sequence) consisting of two long SL structures (Fig. $5 \mathrm{~b})$. The $5^{\prime}$ most SL consisted of 166 nt $(18,333-18,498)$ and the 3 'most structure with 83 nt $(18,240-18,322)$

\section{Mapping the transcription start sites of the most abundant sgRNAs revealed differences with other monopartite members of the family Closteroviridae}

The members of the genera Closterovirus and Crinivirus employ the production of sgRNAs to serve as messengers for specific genes as one of the adaptive strategies to express their polycistronic genomes in their hosts [4-6]. As a first step toward understanding strategies underlying production of the sgRNAs of viruses in the genus Ampelovirus, we mapped the $5^{\prime}$ termini of the four most abundantly expressed genes in relation to the genomic RNA of GLRaV-3. For this purpose, the 5' ends of CP, p21, p20A and p20B sgRNAs were RT-PCR amplified by the 5 RACE system from total RNA isolated from grapevine tissue infected with GLRaV-3 using a combination of an abridged anchor primer and gene-specific primer, and the amplicons were cloned into pGEM-T vector. Sequences obtained from six independent clones for each of the sgRNAs were identical and were subsequently used to map the exact nucleotide position of the 5 '-end of each sgRNA. The results showed that the length of sequence between the $5^{\prime}$-end and the putative start codon of each ORF (sgRNA leader sequence) is $48,23,95$ and $125 \mathrm{nt}$, respectively, for $\mathrm{CP}$, p21, p20A and p20B sgRNAs (Fig. 6a). This data demonstrated that the four sgRNAs have distinctly different sizes of mRNA leader sequences that are collinear with the genomic RNA. All four sgRNAs started with an adenylate, similar to the $5^{\prime}$-end of the genomic RNA. Based on this information, the transcription start site (TSS) for CP, p21, p20A and p20B was located at $13,800,16,273,16,755$ and $17,265 \mathrm{nt}$, respectively, in the genome sequence of the Washington isolate of GLRaV3 (Additional file 1, Table S3). The 48 nt leader sequence of CP sgRNA is located entirely in the intergenic region (IGR) between p55 and CP, the 23 nt leader sequence of p21 encompass 13 nt C-terminus of $\mathrm{CPm}$ ORF and 10 nt IGR between CPm and p21, the 95 nt leader sequence of p20A overlaps with the C-terminus of $\mathrm{p} 21$, and the $125 \mathrm{nt}$ leader sequence of $\mathrm{p} 20 \mathrm{~B}$ encompass $119 \mathrm{nt} \mathrm{C}$-terminal portion of $\mathrm{p} 20 \mathrm{~A}$ and $6 \mathrm{nt}$ IGR between $\mathrm{p} 20 \mathrm{~A}$ and $\mathrm{p} 20 \mathrm{~B}$. Using the location of TSS, we estimated the size of sgRNA for CP, p21, p20A and p20B (Fig. 6a) as 4,699, 2,226, 1,744 and 1,234 nts, respectively (Additional file 1 , Table S3). The TSS for CP, p20A and p20B sgRNAs match with those reported for South African isolate of GLRaV-3 [31]. The study by Maree et al. [31] also indentified TSS for the other 3' sgRNAs. However, we could not amplify 5 '-end sequences for the other sgRNAs (ORFs 2, 3, 4, 5, and 
a

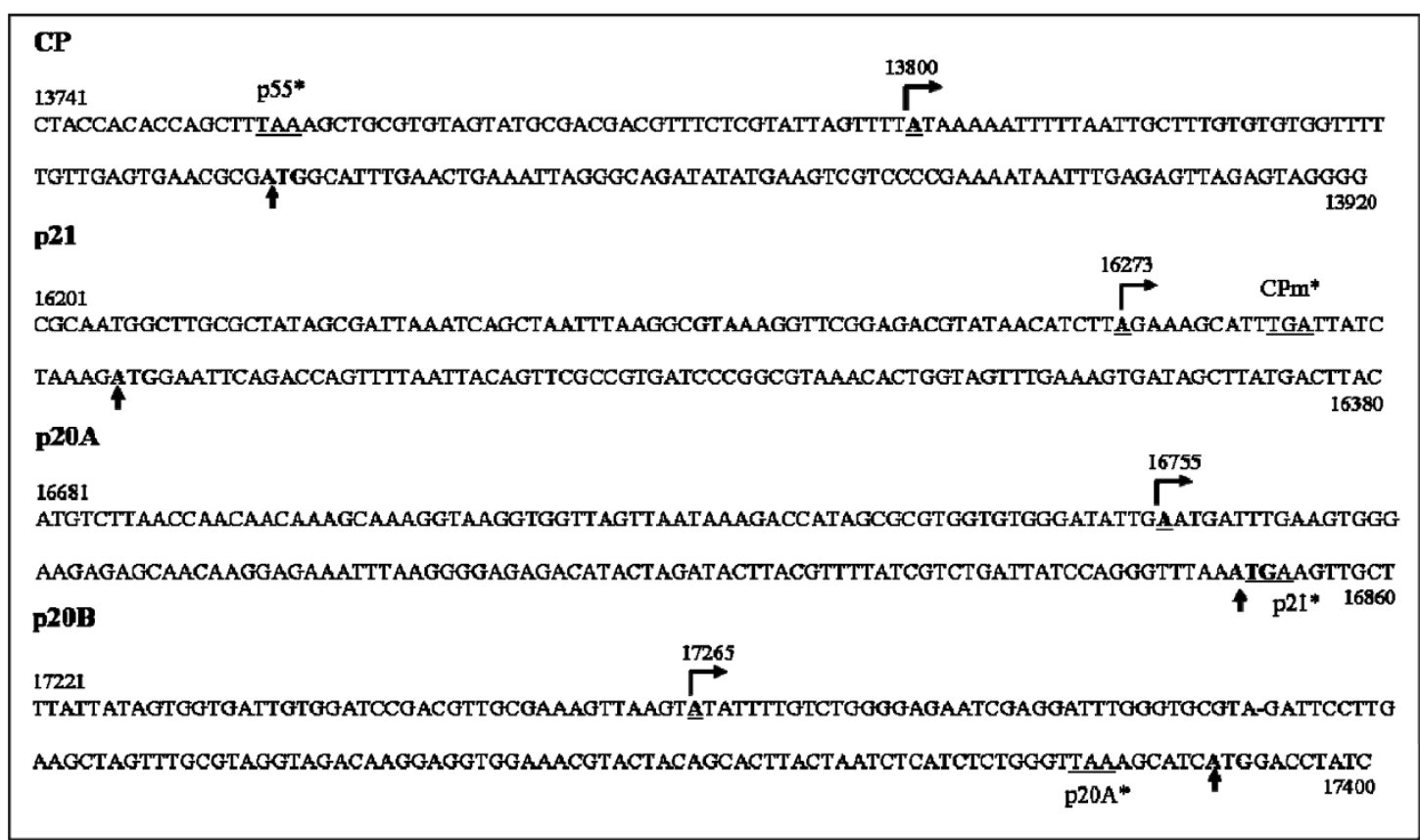

b

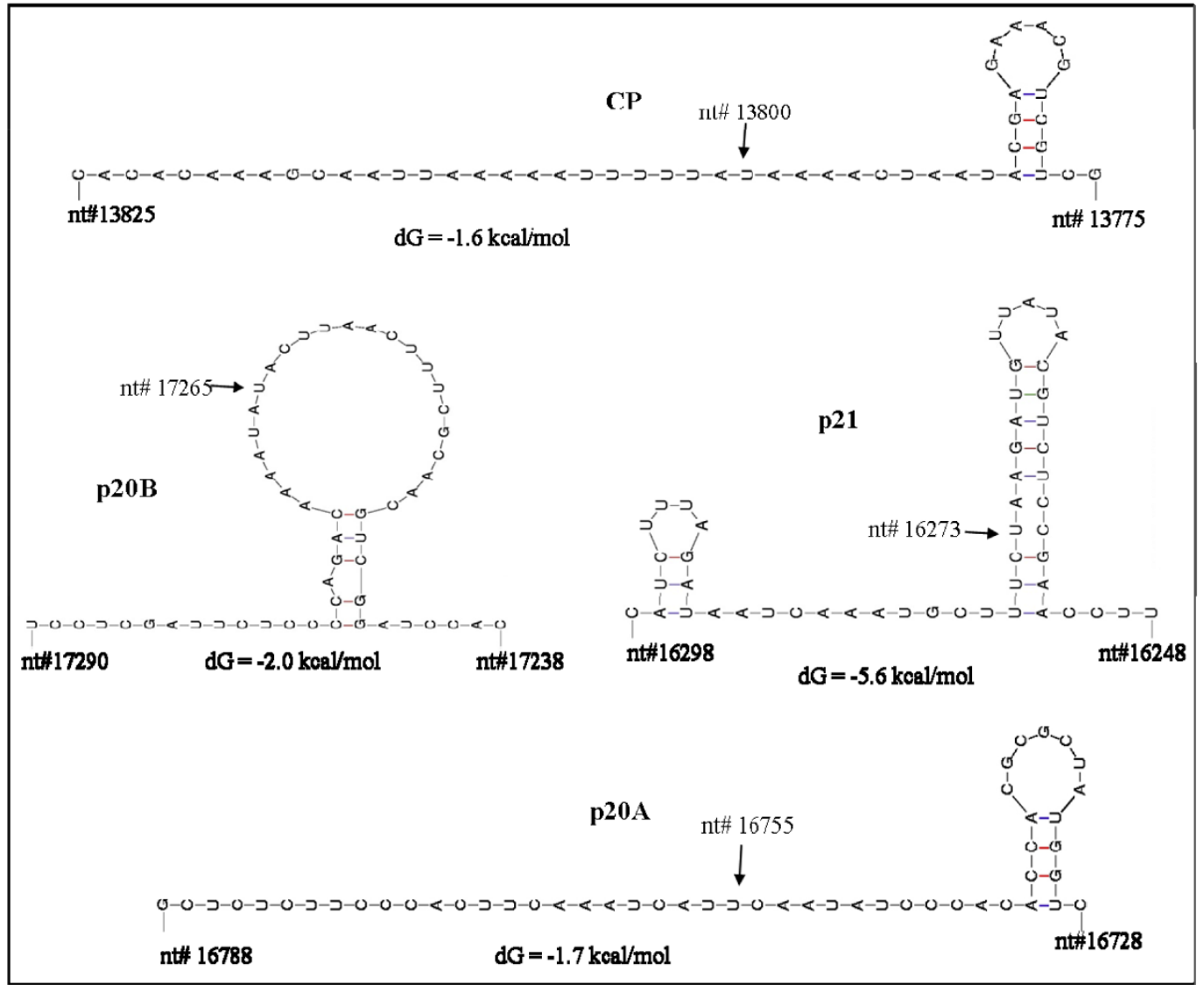

Figure 6 Transcription start site (TSS) of four subgenomic (sg) RNAs. (a) Nucleotide sequence of the portion of the genomic RNA showing the TSS of sgRNAs specific to CP, p21, P2OA and p20B and (b) the predicted secondary structure of the minus-strand sequences around the TSS of the sgRNAs. Numbers indicate nucleotide coordinates with the genomic RNA. The TSS is indicated by a bent arrow (with +1 adenylate underlined) in (a) and by an arrow in (b), termination codon of the preceding ORF is underlined and marked with an asterisk and the translation initiation codon is in bold and marked with an arrow. 
7), despite several attempts, possibly due to their low abundance in infected grapevine tissue.

The $5^{\prime}$ leader sequences of $\mathrm{CP}, \mathrm{p} 21, \mathrm{p} 20 \mathrm{~A}$ and $\mathrm{p} 20 \mathrm{~B}$ of the Washington isolate were more similar (98-100\% identity) to the corresponding sequences in the New York and Chile isolates than with South Africa isolate (88-94\% identity) (Additional file 1, Table S4). Except for the 5'-end nucleotide, the leader sequences of the four sgRNAs did not reveal any shared sequence motifs, in contrast with the presence of a conserved heptanucleotide in some sgRNAs of BYV and CTV [16]. Since conserved nucleotide sequences around the TSS of sgRNA were implicated in the synthesis of sgRNAs of Tobacco mosaic virus (TMV) [32] and Citrus tatter leaf virus (CTLV) [33], we compared a $50 \mathrm{nt}$ region around the TSS $(-25$ to +25 relative to the initiation site of each sgRNA) of each of the four sgRNAs of GLRaV-3. The results revealed no conserved sequences surrounding the TSS, in contrast to the presence of conserved octanucleotide sequences in TMV and CTLV.

The sequences upstream of the ORFs of CTV were shown to control production of sgRNAs [13,14]. In general, the minus strands corresponding to these regions could be folded into one or two SL structures with the first nucleotide (A) of the sgRNA leader a few nucleotides downstream of the last SL structure [34]. To predict the possible involvement of RNA secondary structures in the sgRNA synthesis analogous to TMV, CTLV and CTV, the $50 \mathrm{nt}$ sequence corresponding to the minus strand sequence around the TSS of the four sgRNAs was analyzed by MFOLD [30]. The results showed that, although the $50 \mathrm{nt}$ sequence corresponding to the minus strand sequence of sgRNAs for CP, p21, p20A and p20B folded into predicted SL structures, conservation of the predicted secondary structures was not observed (Fig. 6b). The 5'end nucleotide of sgRNA specific to CP and p20A was located outside the SL structure, whereas that specific to p21 sgRNA was located on the stem of the SL structure and it was in the loop in the case of p20B sgRNA. The integrity of these secondary structural features were maintained in the leader sequences of all GLRaV-3 isolates, despite low (84-94\%) sequence identity especially between Washington and South Africa isolates, suggesting a requirement for the putative secondary structure in sgRNA synthesis. The genome sequences immediately $\sim 100 \mathrm{nt}$ upstream from the $5^{\prime}$ terminus of each sgRNA were also compared to verify the possible conservation in the putative control elements for sgRNA production. The data revealed no similarity between the sequences or their predicted structures and no structures similar to those found for CTV.

\section{Discussion}

Synthesis of 3'-coterminal sgRNAs is one of the genome expression strategies adapted by members of the family
Closteroviridae. Evidence gathered with viruses in the genera Closterovirus [4,6] and Crinivirus [5,18,35] demonstrated that the temporal expression and kinetics of accumulation of these sgRNAs is highly regulated and level of sgRNAs expressed depends on promoter strength and position within the genome. However, expression strategies of sgRNAs for members of the genus Ampelovirus have not been studied to date, despite their economic importance to many agriculturally important crops. The characteristic profiles of sgRNAs obtained in Northern blots from virus-infected grapevine (Fig. 2) provided evidence that GLRaV-3 likely employs a strategy for the expression of its nested set of 3 '-coterminal sgRNAs similar to other closteroviruses. However, accumulation of sgRNAs detected in virusinfected grapevine tissue indicated differences in the levels of expression of specific sgRNAs compared to other monopartite closteroviruses like BYV and CTV $[15,16,36,37]$. Since results of this study were from an asynchronous infection, it is possible that the amounts and timing of synthesis of sgRNAs in GLRaV-3-infected tissue are variable during the growing season and remains to be elucidated to determine whether their profile changes in relation to the developmental stage or expression of grapevine leafroll disease symptoms [19].

The sgRNAs for $\mathrm{p} 7$ and $\mathrm{p} 4 \mathrm{ORFs}$, located close to the 3' terminus of GLRaV-3 genome, accumulated at lower levels than sgRNAs specific to upstream ORFs p20B, p20A and p21. Similarly, the sgRNA specific to the CP showed higher accumulation than the sgRNA specific to $\mathrm{CPm}$, which is closer to the $3^{\prime}$ terminus. Another unique feature of GLRaV-3 is that the sgRNAs specific to $\mathrm{p} 21$ ORF, which has only a 10 nt 5 'nontranslated region upstream of the ORF where a cis-acting promoter element would be expected to occur, and the sgRNA corresponding to the $\mathrm{p} 20 \mathrm{~A}$ ORF, which lacks an upstream nontranslated region due to overlap with the upstream p21 ORF, accumulate at more or less similar levels compared to sgRNA of the CP ORF that has an $89 \mathrm{nt}$ upstream nontranslated region. These results clearly suggest that GLRaV-3 does not follow either of the two general rules: (i) genes located nearer the 3 'terminus are usually expressed at higher levels and (ii) ORFs with a $5^{\prime}$ nontranslated region are generally expressed higher than ORFs that overlap with the upstream ORF (and hence no nontranslated region). Instead, it is likely that production of GLRaV-3 sgRNAs follows an alternative or modified mechanism.

The mapping of $5^{\prime}$ termini of four $3^{\prime}$-terminal genes (CP, p21, p20A and p20B) of GLRaV-3 indicated that they possess a +1 adenylate, same as the $5^{\prime}$ end of the genome, and this observation was analogous to CTV than to other closteroviruses like BYV [16-18]. The leader sequences of GLRaV-3 sgRNAs are collinear with 
the genomic RNA and their relative lengths are within the range observed for sgRNAs of CTV and BYV. The first few nucleotides of the $5^{\prime}$ end of the genomic RNA (ATAAATG) and the genomic sequence around the $5^{\prime}$ termini of sgRNAs (underlined, CP [TTTTATAAA], p21 [TCTTAGAAA], p20A [ATTGAATGA], p20B [AAGTATATT]) were similar but not identical AU-rich regions. Presence of an adenylate as the $5^{\prime}$ terminus in the genomic and all four sgRNAs suggested that initiation of RNA synthesis from an uridylate on the minus strand is preferred by the GLRaV-3 replicase complex, similar to that proposed for CTV [15]. However, the lack of sequence conservation around the $5^{\prime}$ termini and the absence of secondary structure elements or octanucleotides conserved in BYV and CTV nontranslated leader regions suggest that sgRNA expression strategy in GLRaV-3 could be somewhat different leading to the hypothesis that some commonalities do exist in the replication strategy between closteroviruses and ampeloviruses, but also some features characteristic to ampeloviruses.

In this study, the complete genomic RNA sequence of GLRaV-3 was determined to consist of $18,498 \mathrm{nt}$ and is in agreement with the size of GLRaV-3 isolate reported from South Africa [23]. The overall genome organization of these two isolates is similar to that of GLRaV-3 isolates sequenced from New York and Chile. All four isolates have highly conserved $3^{\prime}$ NTRs than $5^{\prime}$ NTRs due to the unusual variation in size and sequence between them. Given the same size 5'NTR in two GLRaV-3 genome sequences obtained by independent groups in distant locations [this study and 23], it is likely that artifacts in cloning would have resulted in the apparent small size $5^{\prime}$ NTR reported for New York and Chile isolates. It could be possible that use of poly (A) tailing to amplify the $5^{\prime}$ NTR and the likelihood of non-specific annealing of oligo (dT) primer to a portion of $5^{\prime}$ NTR with high adenines in the complementary DNA strand of GLRaV-3 would have contributed to the amplification of less-than full size sequence at the $5^{\prime}$ terminal portion of the genome [26]. The 5'portion of GLRaV-3 isolate from Chile was amplified by RT-PCR using primers designed based on the sequence of New York isolate [27] and hence may not be a true representation of the authentic 5'end of virus genome. In contrast, our study and that reported from South Africa [23] used 5'RACE to accurately map the 5'end of GLRaV-3 genome. Additionally, same size PCR products with high level of sequence similarity amplified from GLRaV-3 isolates originating from different grapevine cultivars planted in geographically distinct locations in the US provided additional evidence that the size of $5^{\prime} \mathrm{NTR}$ determined in our study is accurate.

A 737 nt long $5^{\prime} \mathrm{NTR}$ in GLRaV-3 genome represents the longest $5^{\prime} \mathrm{NTR}$ among the currently known monopartite members of the family Closteroviridae available in database. The sizes of $5^{\prime} \mathrm{NTR}$ in viruses of the genus Closterovirus is between 105 and $227 \mathrm{nt}$ and those in the genus Ampelovirus between 213 and 737 nt, respectively. In contrast, the bipartite and tripartite members of the genus Crinivirus have 72 to 264 nt $5^{\prime}$ NTR in RNA 1 . Thus, highly variable size of $5^{\prime}$ NTR appears to be a characteristic of the members in the genus Ampelovirus in the family Closteroviridae. In addition, the $5^{\prime}$ NTRs of grapevine-infecting closteroviruses, such as GLRaV-1, GLRaV-2 and GLRaV-Pr, for which complete genome sequences are available in the database, are variable in size with no significant sequence homology between them. Outside of the family Closteroviridae, a long 5'NTR of 739 nt was recently observed in Triticum mosaic virus (TriMV), a wheatinfecting virus in the family Potyviridae [38]. To our knowledge, GLRaV-3 and TriMV appears to be the only plant viruses with monopartite genome known to date with such a long sequence in their $5^{\prime}$ NTR. A long $5^{\prime}$ NTR in plant viruses is unusual, but a long $5^{\prime}$ NTR ranging in length from 610 to $1500 \mathrm{nt}$ has been reported in animal/human-infecting viruses in the family Picornaviridae [39]. Unlike 5'NTRs of TriMV and picornaviruses, which contain multiple non-conserved AUG upstream of the initiation codon, the $737 \mathrm{nt}$ long 5'NTR of GLRaV-3 isolates contain only one AUG triplet at the very 5 'terminus (5'-ATAAATGCTC) preceding the translation initiation codon of the ORF1 polyprotein. Thus, the long $5^{\prime} \mathrm{NTR}$ of GLRaV-3 appears to have features distinct from other plant and animal infecting viruses. The $5^{\prime}$ NTR sequences in many picornaviruses and flaviviruses are highly structured to form internal ribosome entry (IRES) elements that play a role in protein translation in a cap-independent manner [40]. It remains to be studied if any potential IRES elements exist in the $5^{\prime} \mathrm{NTR}$ of GLRaV-3. At a practical level, the high variability in $5^{\prime}$ NTR could be useful for discriminating GLRaV-3 isolates from different grape-growing areas around the world into phylogenetically distinct lineages.

In the case of CTV, the $5^{\prime} \mathrm{NTRs}$ of all isolates could be folded into two similar stem-loop structures despite the fact that their sequence varied by as much as $58 \%$ [41]. These two conserved structures were shown to be important for replication and assembly $[7,42]$. Even though we showed a complex secondary structure for $5^{\prime}$ NTR of GLRaV-3 isolates (Fig. 5a) as predicted by using the MFOLD program, the complex structures did not seem to be conserved between the Washington and South Africa isolates. A tandem repeat of $65 \mathrm{nt}$ in the $5^{\prime}$ NTR sequence of many GLRaV-3 isolates from the US, but not in the $5^{\prime}$ NTR of the South Africa isolate, is surprising and the functional importance of this repeat 
sequence in virus life cycle needs to be examined. In contrast to the $5^{\prime} \mathrm{NTR}$, the $3^{\prime} \mathrm{NTR}$ of the four GLRaV-3 isolates is highly conserved and folded into identical secondary structure (Fig. 5b). This pattern is analogous to CTV, but different from BYV, where different isolates were shown to have considerable differences in size and sequence identity in the $3^{\prime} \mathrm{NTR}$ [28]. It has been shown with CTV that the $3^{\prime} \mathrm{NTR}$ contains cis-acting elements required to initiate synthesis of complementary negative strands and some of the predicted secondary structures are important components for efficient replication [43] and it is likely that the predicted SL structures in the $3^{\prime}$ NTR contain cis-acting elements to play a critical role in GLRaV-3 replication.

\section{Conclusions}

This study has shown that four of the eleven putative 3'coterminal sgRNAs were abundantly present in the total RNA extracted from grapevine naturally infected with GLRaV-3 in Northern blots using gene-specific riboprobes. The $5^{\prime}$ termini of sgRNAs specific to CP, p21, p20A and p20B were mapped in the virus genome and their leader sequences determined to be $48,23,95$, and $125 \mathrm{nt}$, respectively, and they were collinear with the genomic RNA. The lack of conserved motifs around the transcription start site or in the leader sequences of these sgRNAs indicated that transcription regulation of GLRaV-3 sgRNAs could be different from members of the genus Closterovirus and suggests the lack of evolutionary conservation in the regulation of gene transcription among monopartite members of the family Closteroviridae. The $5^{\prime} \mathrm{NTR}$ of GLRaV-3 has an unusually long $5^{\prime}$ NTR of 737 nt compared to other members of the family Closteroviridae and showed distinct differences in the sequence and predicted secondary structure between two distinct isolates of GLRaV-3. Availability of an infectious cDNA clone of GLRaV-3 would clearly help to explore the mechanism(s) by which the 3'-coterminal sg-mRNAs are produced and make comparative assessment of replication strategies among members of the genera Closterovirus and Ampelovirus and their adaptation to disparate plant hosts and insect vectors.

\section{Methods}

Virus source and preparation of double-stranded RNA

GLRaV-3 isolates were collected from five wine grape cultivars (Vitis vinifera, cvs. Cabernet Sauvignon, Syrah, Merlot, Chardonnay), one table grape cultivar (V. vinifera, cv. Thomson Seedless) and one juice grape cultivar (V. labruscana 'Concord'). Cambial scrapings of canes from a single Merlot grapevine were used for isolating genomic-length replicative-form double-stranded (ds) RNA essentially as described by Valverde et al. [44].
The integrity of dsRNA preparations were verified by resolving in $0.8 \%$ agarose gels and using dsRNAenriched preparation from citrus (Sour Orange) infected with Citrus trizteza virus (CTV). Unless otherwise mentioned, the same dsRNA preparation was used for cloning and sequencing of the entire genome of GLRaV-3.

\section{CDNA synthesis, RT-PCR, cloning and sequence analyses}

The denatured dsRNA served as a template for cDNA synthesis. The reaction was carried out in $25 \mu \mathrm{L}$ reaction mixture in the presence of gene-specific complementary primer using Superscript III reverse transcriptase kit (Invitrogen Corp, Carlsbad, CA) by following the manufacturer's instructions. The cDNA preparation was used as a template for subsequent PCR amplification of different portions of the virus genome (Additional file 1, Figure S1) using primers listed in Additional file 1, Table S1). These primers were initially designed based on nucleotide sequence information available for New York isolate of GLRaV-3 (AF037268), [26]. Primers for subsequent experiments were designed based on the sequence obtained for GLRaV-3 isolate from Washington (accession no. GU983863). Unless stated otherwise, locations of all primers were indicated using the entire genome sequence of GLRaV-3 isolate from Washington. Each PCR reaction in $20 \mu \mathrm{L}$ consisted of a final concentration of 2-4 ng of template cDNA, 0.3 $\mu$ Moles each of sense and antisense primers, $0.2 \mathrm{mM}$ of each dNTP, $1 \mathrm{X}$ concentration of reaction buffer consisting $1 \mathrm{mM} \mathrm{Mg}^{2+}$ and $0.025 \mathrm{U}$ of high fidelity Takara Prime Star DNA polymerase (Takara Bio Inc., Japan). The temperature profile for the amplification included denaturation at $94^{\circ} \mathrm{C}$ for $30 \mathrm{sec}$ followed by 35 cycles of denaturation at $98^{\circ} \mathrm{C}$ for $10 \mathrm{sec}$, annealing at $60^{\circ} \mathrm{C}$ for 5 sec and extension at $72^{\circ} \mathrm{C}$ for $60 \mathrm{sec}$ per $1 \mathrm{~kb}$ size of amplicon and a final extension at $72^{\circ} \mathrm{C}$ for 10 minutes.

The amplicons were cloned in pUC-119 based vector and two independent clones specific to each amplicon were sequenced in both orientations at the Molecular Biology Core Instrumentation Facility, Washington State University, Pullman, WA. Wherever necessary, additional clones were sequenced to resolve nucleotide sequence ambiguities. Nucleotide and predicted amino acid sequences were analyzed using Vector NTI Advance11 software (Invitrogen Corp, Carlsbad, CA).

\section{Rapid amplification of cDNA ends of GLRaV-3}

The exact $5^{\prime}$ end sequence of GLRaV-3 was determined using a commercially available $5^{\prime}$ RACE system for rapid amplification of cDNA ends kit (Version 2.0, Invitrogen, Carlsbad, CA). Total RNA was isolated from bark scrapings of canes collected from GLRaV-3-infected Merlot vines based on a protocol reported by Tattersall et al. [45]. First-strand cDNA was synthesized using the gene- 
specific primer AR (5'-CATTAAGGGCCCTGTTAAAC$3^{\prime}$, complementary to nucleotides 833 to 852 of the Washington isolate, GU983863). The purified firststrand cDNA was ' $\mathrm{dC}$ ' tailed and the following primer combinations were used to amplify virus-specific DNA fragments: virus-specific primer M1012 (5'-AAGTCCGACAACTTCACGTTCCCT-3', complementary to nucleotides 860 to 883 in GU983863) and the abridged anchor primer (AAP) supplied with the kit and virusspecific primer M1013 (5'-AAGTTGAGGTCCTTG CCTCCATCAAG-3', complementary to nucleotides 1034 to 1059 in GU983863) and the AAP supplied with the kit. The temperature profile for the amplification of DNA included denaturation at $94^{\circ} \mathrm{C}$ for 3 min followed by 35 cycles of denaturation at $94^{\circ} \mathrm{C}$ for $10 \mathrm{sec}$, annealing at $56^{\circ} \mathrm{C}$ for $30 \mathrm{sec}$ and extension at $72^{\circ} \mathrm{C}$ for $60 \mathrm{sec}$ and a final extension at $72^{\circ} \mathrm{C}$ for $5 \mathrm{~min}$.

For verification of $3^{\prime}$ end sequence of GLRaV-3, total RNA was poly-adenylated with Yeast Poly(A) polymerase (USB, Cleveland, $\mathrm{OH}$ ) and used for cDNA synthesis using SuperScriptIII reverse transcriptase (Invitrogen, Carlsbad, CA). The first-strand cDNA was used as a template to amplify virus-specific DNA using an oligo dT primer M111 (5'-GGTCTCGAG(T) $18^{\prime}-3^{\prime}$ ) and a virus-specific forward primer GF (5'-ATTAGCATATGTAGAAAAGGGGAAG-3', nucleotides 18174 to 18198 in GU983863). The $5^{\prime}$ and $3^{\prime}$ RACE PCR products were cloned into pGEM-T vector (Promega, Madison, WI) and six independent clones specific to each PCR product were sequenced in both orientations. Sequences were analyzed as described above.

\section{Riboprobe preparation and Northern blot hybridization}

Total RNA extracts prepared from cambial scrapings collected from GLRaV-3-infected Merlot grapevines were separated by electrophoresis in a formaldehyde denaturing $1.1 \%$ agarose gel in MOPS buffer, and transferred onto a nylon membrane using an electrotransfer unit (Hoefer Pharmacia Biotech, San fransisco, CA) as described by Lewandowski and Dawson [46]. Northern blot hybridization and probing of membranes for the presence of genomic RNA and subgenomic RNAs of GLRaV-3 with nonradioactive digoxigenin (DIG)-labeled riboprobes was carried out according to Tatineni et al. [33]. The probe for detecting all sgRNAs includes $17,899-18,498 \mathrm{nt}$ at the $3^{\prime}$ terminus of the Washington isolate of GLRaV-3 (Additional file 1, Table S5). DNA template for gene-specific riboprobe synthesis were amplified from virus-specific clones in pUC119 using the primers listed in Additional file 1, Table S5 and Table S6. T7 and SP6 polymerase promoter sequences were included in the forward and reverse primers, respectively, and the PCR amplified products were agarose-gel eluted and used as a template to generate positive-stranded RNA-specific probes by using T7- or SP6-RNA polymerase and nucleotides containing DIGlabeled UTP.

\section{Mapping the transcription start sites of GLRaV-3-sgRNAs}

Total RNA isolated from cambial scrapings of GLRaV-3infected Merlot grapevine was used to map the transcription start sites of four sgRNAs, namely, CP, p21, p20A and $\mathrm{p} 20 \mathrm{~B}$. The gene specific primers (Additional file 1, Table S7) were used to synthesize the first-strand cDNAs. The first-strand cDNAs were column purified and ' $\mathrm{dC}$ ' tailed at the 5 ' end using terminal deoxynucleotidyl transferase, and amplified by using $2.5 \mathrm{U}$ of Taq DNA polymerase (New England Biolabs, Ipswich, MA) in a $50 \mu \mathrm{L}$ reaction volume with an abridged anchor primer (supplied with kit) together with gene specific nested primer. The following conditions were used for PCR: 1 cycle at $94^{\circ} \mathrm{C}$ for $2 \mathrm{~min}$, followed by 35 cycles at $94^{\circ} \mathrm{C}$ for $20 \mathrm{sec}, 56^{\circ} \mathrm{C}$ for $20 \mathrm{sec}$ and $72^{\circ} \mathrm{C}$ for $1 \mathrm{~min}$, and one cycle at $72^{\circ} \mathrm{C}$ for $5 \mathrm{~min}$. The PCR products were ligated into pGEM-T Easy vector (Promega, WI) and the inserts were sequenced at the DNA sequencing Core, Interdesciplinary Center for Biotechnology Research, University of Florida, Gainesville, FL.

\section{Sequence analysis}

Sequences were edited and assembled using ContigExpress module in the VectorNTI sequence analysis software package (Invitrogen Corp, Carlsbad, CA). Nucleotide and amino acid sequence identity levels were calculated using Vector NTI Advance program (Invitrogen Corp. CA). Secondary structure analysis of the $5^{\prime}$ NTR and $3^{\prime}$ NTR sequences was carried out by using MFOLD software [30].

\section{Additional material}

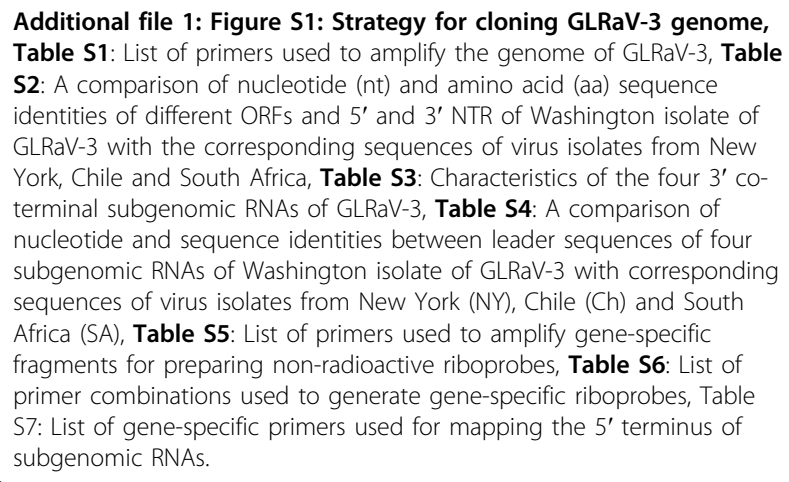

\section{Acknowledgements}

This work was supported in part by Washington State University's New Faculty Seed Grant Program, Agricultural Research Center and Agricultural 
Program in Extension in the College of Agricultural, Human, and Natural Resource Sciences, and Washington Wine Commission's Wine Advisory Committee. PPNS \# 0544, Department of Plant Pathology, College of Agricultural, Human, and Natural Resource Sciences Agricultural Research Center Project No. WNPO 0616, Washington State University, Pullman, WA 99164-6240, USA.

\section{Author details}

${ }^{1}$ Department of Plant Pathology, Irrigated Agriculture Research and Extension Center, Washington State University, Prosser, WA 99350, USA. ${ }^{2}$ Citrus Research and Education Center, University of Florida, Lake Alfred, FL 33850, USA.

\section{Authors' contributions}

RAN conceived and designed the study. SJ performed the research. SJ, SG, WOD and RAN analyzed the results and wrote the manuscript. All authors read and approved the final manuscript.

\section{Competing interests}

The authors declare that they have no competing interests.

Received: 14 June 2010 Accepted: 3 August 2010

Published: 3 August 2010

\section{References}

1. Karasev AV: Genetic diversity and evolution of closteroviruses. Annu Rev Phytopathol 2000, 38:293-324

2. Martelli GP, Agranovsky AA, Bar-Joseph M, Boscia D, Candresse T, Coutts RHA, Dolja W, Falk BW, Gonsalves D, Jelkmann W, Karasev AV, Minafra A, Namba S, Vetten HJ, Wisler GC, Yoshikawa H: The family Closteroviridae revised. Arch Virol 2002, 147:2039-2044.

3. Dolja W: Beet yellows virus: the importance of being different. Molecular Plant Pathology 2003, 4:91-98.

4. Dolja W, Kreuze JF, Valkonen JPT: Comparative and functional genomics of closteroviruses. Virus Res 2006, 117:38-51.

5. Salem NM, Chen AY, Tzanetakis IE, Mongkolsiriwattana C, Ng JC: Further complexity of the genus Crinivirus revealed by the complete genome sequence of Lettuce chlorosis virus (LCV) and the similar temporal accumulation of LCV genomic RNAs 1 and 2. Virology 2009, 390:45-55.

6. Dawson WO: Molecular genetics of Citrus tristeza virus. Citrus tristeza virus Complex and Tristeza Diseases St. Paul, MN: American Phytopathological SocietyKarasev AV, Hilf ME 2010, 53-72.

7. Satyanarayana T, Gowda S, Ayllón MA, Dawson WO: Closterovirus bipolar virion: Evidence for initiation of assembly by minor coat protein and its restriction to the genomic RNA 5' region. Proc Natl Acad Sci USA 2004, 101:799-804.

8. Peremyslov W, Andreev IA, Prokhnevsky Al, Duncan GH, Taliansky ME, Dolja W: Complex molecular architecture of Beet yellows virus particles. Proc Natl Acad Sci USA 2004, 101:5030-5035.

9. Satyanarayana T, Robertson CJ, Garnsey SM, Bar-Joseph M, Gowda S, Dawson WO: Three genes of Citrus tristeza virus are dispensable for infection and movement throughout some varieties of citrus trees. Virology 2008, 376:297-307.

10. Liu YP, Peremyslov W, Medina V, Dolja W: Tandem leader proteases of Grapevine leafroll-associated virus 2: host-specific functions in the infection cycle. Virology 2009, 383:291-299.

11. Wang J, Turina M, Stewart LR, Lindbo JA, Falk BW: Agroinoculation of the crinivirus, Lettuce infectious yellows virus, for systemic plant infection. Virology 2009, 392:131-136.

12. Gowda S, Satyanarayana T, Folimonova SY, Hilf ME, Dawson WO: Accumulation of a $5^{\prime}$ proximal subgenomic RNA of Citrus tristeza virus is correlated with encapsidation by the minor coat protein. Virology 2009, 389:122-131.

13. Gowda S, Satyanarayana T, Ayllón MA, Albiach-Martí MR, Mawassi M, Rabindran S, Garnsey SM, Dawson WO: Characterization of the cis-acting elements controlling subgenomic mRNAs of Citrus tristeza virus: production of positive- and negative-stranded 3'-terminal and positivestranded 5'-terminal RNAs. Virology 2001, 286:134-151.

14. Ayllón MA, Satyanarayana T, Gowda S, Dawson WO: An atypical 3'controller element mediates low-level transcription of the p6 subgenomic mRNA of Citrus tristeza virus. Molecular Plant Path 2005 6:165-176.

15. Ayllón MA, Gowda S, Satyanarayana T, Karasev AV, Adkins S, Mawassi M, Guerri J, Moreno P, Dawson WO: Effects of modification of the transcription initiation site context on Citrus tristeza virus subgenomic RNA synthesis. J Virol 2003, 77:9232-9243.

16. Peremyslov W, Dolja W: Identification of the subgenomic mRNAs that encode 6-kDa movement protein and Hsp70 homolog of Beet yellows virus. Virology 2002, 295:299-306.

17. Vitushkina MV, Rogozin IB, Jelkmann W, Koonin EV, Agranovsky AA: Completion of the mapping of transcription start sites for the five-gene block subgenomic RNAs of Beet yellows Closterovirus and identification of putative subgenomic promoters. Virus Research 2007, 128:153-158.

18. Kreuze JF, Savenkov El, Valkonen JPT: Complete genome sequence and analyses of the subgenomic RNAs of Sweet potato chlorotic stunt virus reveal several new features for the genus Crinivirus. J Virol 2002, 76:9260-9270.

19. Rayapati AN, O'Neil S, Walsh D: Grapevine leafroll disease, EB2027E. WSU Extension Bulletin 2008.

20. Sether DM, Hu JS: Yield impact and spread of Pineapple mealybug wilt associated virus-2 and mealybug wilt of pineapple in Hawaii. Plant Dis 2002, 86:867-874.

21. Bajet NB, Unruh TR, Druffel KL, Eastwell KC: Occurrence of two little cherry viruses in sweet cherry in Washington State. Plant Dis 2008, 92:234-238.

22. Al Rwahnih M, Uyemoto JK, Falk BW, Rowhani A: Molecula characterization and detection of Plum bark necrosis stem pitting associated virus. Arch Virol 2007, 152:2197-2206.

23. Maree HJ, Freeborough MJ, Burger JT: Complete nucleotide sequence of a South African isolate of Grapevine leafroll-associated virus 3 reveals a 5' UTR of 737 nucleotides. Arch Virol 2008, 153:755-757.

24. Karasev AV, Boyko VP, Gowda S, Nikolaeva OV, Hilf ME, Koonin EV, Niblett CL, Cline K, Gumpf DJ, Lee RF, Garnsey SM, Lewandowski DJ, Dawson WO: Complete sequence of the citrus tristeza virus RNA genome. Virology 1995, 208:511-520.

25. Turturo C, Saldarelli P, Yafeng D, Digiaro M, Minafra A, Savino V, Martelli GP: Genetic variability and population structure of Grapevine leafrollassociated virus 3 isolates. J Gen Virol 2005, 86:217-224.

26. Ling KS, Zhu HY, Gonsalves D: Complete nucleotide sequence and genome organization of Grapevine leafroll-associated virus 3, type member of the genus Ampelovirus . J Gen Virol 2004, 85:2099-2102.

27. Engel EA, Girardi C, Escobar PF, Arredondo V, Dominguez C, Perez-Acle T, Valenzuela PDT: Genome analysis and detection of a Chilean isolate of Grapevine leafroll associated virus 3. Virus Genes 2008, 37:110-118.

28. Peremyslov W, Hagiwara Y, Dolja W: Genes required for replication of the 15.5-kilobase RNA genome of a plant closterovirus. J Virol 1998, 72:5870-5876.

29. Satyanarayana T, Gowda S, Ayllón MA, Albiach-Martí MR, Rabindran S, Dawson WO: The p23 protein of Citrus tristeza virus controls asymmetrical RNA accumulation. J Virol 2002, 76:473-483.

30. Zuker M, Mathews DH, Turner DH: Algorithms and thermodynamics for RNA secondary structure prediction. A practical guide. RNA Biochemistry and Bio/Technology Dordrecht/Norwell, MA: Kluwer Academic PublishingBarciszewski J, Clark BFC 1999, 11-43.

31. Maree HJ, Gardner HFJ, Freeborough MJ, Burger JT: Mapping of the $5^{\prime}$ terminal nucleotides of Grapevine leafroll associated virus 3 sgRNAs. Virus Res 2010, 151:252-255.

32. Grdzelishvili VG, Chapman SN, Dawson WO, Lewandowski DJ: Mapping of the Tobacco mosaic virus movement protein and coat protein subgenomic RNA promoters in vivo. Virology 2000, 275:177-192.

33. Tatineni S, Afunian MR, Gowda S, Hilf ME, Bar-Joseph M, Dawson WO Characterization of the $5^{\prime}$ - and 3'-terminal subgenomic RNAs produced by a capillovirus: Evidence for a CP subgenomic RNA. Virology 2009 385:521-528.

34. Ayllón MA, Gowda S, Satyanarayana T, Dawson WO: cis-acting elements at opposite ends of the Citrus tristeza virus genome differ in initiation and termination of subgenomic RNAs. Virology 2004, 322:41-50.

35. Yeh HH, Tian T, Rubio L, Crawford B, Falk BW: Asynchronous accumulation of Lettuce infectious yellows virus RNAs 1 and 2 and identification of an RNA 1 trans enhancer of RNA 2 accumulation. J Virol 2000, 74:5762-5768. 
36. Hilf ME, Karasev AV, Pappu HR, Gumpf DJ, Niblett CL, Garnsey SM: Characterization of Citrus tristeza virus sub- genomic RNAs in infected tissue. Virology 1995, 208:576-582.

37. Satyanarayana T, Gowda S, Boyko VP, Albiach-Martí MR, Mawassi M, NavasCastillo J, Karasev AV, Dolja V, Hilf ME, Lewandowski DJ, Moreno P, BarJoseph M, Garnsey SM, Dawson WO: An engineered closterovirus RNA replicon and analysis of heterologous terminal sequences for replication. Proc Natl Acad Sci USA 1999, 96:7433-7438.

38. Tatineni S, Ziems AD, Wegulo SN, French R: Triticum mosaic virus: A distinct member of the family Potyviridae with an unusually long leader sequence. Phytopathology 2009, 99:943-950.

39. Hellen CUT, Sarnow P: Internal ribosome entry sites in eukaryotic mRNA molecules. Genes Dev 2001, 15:1593-1612.

40. Martinez-Salas E, Pacheco A, Serrano P, Fernandez N: New insights into internal ribosome entry site elements relevant for viral gene expression. J Gen Virol 2008, 89:611-626.

41. López C, Ayllón MA, Navas-Castillo J, Guerri J, Moreno P, Flores R: Molecular variability of the $5^{\prime}$ and $3^{\prime}$ terminal regions of Citrus tristeza virus RNA. Phytopathology 1998, 88:685-691.

42. Gowda S, Satyanarayana T, Ayllón MA, Moreno P, Flores R, Dawson WO: The conserved structures of the $5^{\prime}$ nontranslated region of Citrus tristeza virus are involved in replication and virion assembly. Virology 2003, 317:50-64.

43. Satyanarayana T, Gowda S, Ayllón MA, Albiach-Martí MR, Dawson WO: Mutational analysis of the replication signals in the 3 '-nontranslated region of Citrus Tristeza Virus. Virology 2002, 300:140-152.

44. Valverde R, Nameth $\mathrm{S}$, Jordan R: Analysis of double-stranded RNA for plant virus diagnosis. Plant Dis 1990, 74:255-258.

45. Tattersall EAR, Ergul A, AlKayal F, DeLuc L, Cushman JC, Cramer GR: Comparison of methods for isolating high-quality RNA from leaves of grapevine. Am J Enol Vitic 2005, 56:400-407.

46. Lewandowski DJ, Dawson WO: Deletion of internal sequences results in Tobacco mosaic virus defective RNAs that accumulate to high levels without interfering with replication of the helper virus. Virology 1998 251:427-437.

doi:10.1186/1743-422X-7-180

Cite this article as: Jarugula et al: 3 '-coterminal subgenomic RNAs and putative cis-acting elements of Grapevine leafroll-associated virus 3 reveals 'unique' features of gene expression strategy in the genus Ampelovirus. Virology Journal 2010 7:180.

\section{Submit your next manuscript to BioMed Central and take full advantage of:}

- Convenient online submission

- Thorough peer review

- No space constraints or color figure charges

- Immediate publication on acceptance

- Inclusion in PubMed, CAS, Scopus and Google Scholar

- Research which is freely available for redistribution

Submit your manuscript at www.biomedcentral.com/submit
Biomed Central 